\title{
MicroRNAs as the Potential Regulators of SARS-CoV-2 Infection and Modifiers of the COVID-19 Clinical Features
}

\author{
A. N. Kucher ${ }^{a}$, Iu. A. Koroleva ${ }^{a}$, A. A. Zarubin ${ }^{a}$, and M. S. Nazarenko ${ }^{a}$ * \\ ${ }^{a}$ Research Institute of Medical Genetics, Tomsk National Research Medical Center, Russian Academy of Sciences, \\ Tomsk, 634050 Russia \\ *e-mail: maria.nazarenko@medgenetics.ru
}

Received March 9, 2021; revised May 14, 2021; accepted May 25, 2021

\begin{abstract}
The pandemic of coronavirus disease 2019 (COVID-19) warrants the identification of factors that may determine both risk and severity of infection. The factors include microRNAs that have a wide regulatory potential and hence are particularly interesting. The review focuses on the potential roles of human microRNAs and the viral genome as well as microRNAs in SARS-CoV-2 infection and clinical features of COVID-19. The review summarizes the information about the human microRNAs that are thought to specifically bind to the SARS-CoV-2 genome and considers their expression levels in various organs (cells) in both healthy state and pathologies that are risk factors for severe COVID-19. Potential mechanisms whereby SARS-CoV2 may affect the clinical features of COVID-19 are discussed in brief. The mechanisms include blocking of human microRNAs and RNA-binding proteins, changes in gene expression in infected cells, and possible epigenetic modifications of the human genome with the participation of coronavirus microRNAs.
\end{abstract}

Keywords: microRNA, SARS-CoV-2, COVID-19

DOI: $10.1134 / \mathrm{S} 0026893322010034$

\section{INTRODUCTION}

The spread of coronavirus disease 2019 (COVID-19) due to SARS-CoV-2 respiratory infection caused a pandemic in 2020. COVID-19 affects people of various ages, and its clinical course varies from asymptomatic to severe or critical $[1,2]$. As was noted in systematic reviews that summarized the data on the risk factors and clinical signs and symptoms of COVID-19, a severe disease course and a higher risk of fatal outcome are characteristic of individuals over 60 years of age and patients with certain concomitant disorders, such as hypertension, diabetes mellitus, cardiovascular disorders, and chronic respiratory diseases [3, 4]. In addition, COVID-19 acts as a risk factor for several pathologies, such as virus pneumonia, respiratory insufficiency, kidney failure, sepsis [5], inflammatory damage to blood vessels, damage to the myocardium, arrhythmia [6], thrombotic complications (including acute limb ischemia, abdominal and thoracic aortic thrombosis, myocardial infarction, venous thromboembolism, acute cerebrovascular accident, and disseminated intravascular coagulation) [7], and neurological disorders [8]. It is therefore necessary to identify the endogenous factors that facilitate infection or a severe course of the disease caused by SARS-CoV-2. MicroRNAs attract particular attention as markers of the functional state of the body and molecules with therapeutic potential $[9,10]$.
MicroRNAs are noncoding RNAs of approximately $19-24 \mathrm{nt}$ in length [11, 12]. MicroRNAs are specified as miR-3p or miR-5p depending on what region ( $3^{\prime}$ or $\left.5^{\prime}\right)$ of a double-stranded hairpin precursor gives origin to the respective mature single-stranded sequence [11, 13]. As for the mechanism of action, microRNAs complementarily bind to their target mRNAs to suppress translation or to induce mRNA degradation [14].

MicroRNAs are involved in regulating expression of more than $60 \%$ of all protein-coding genes in mammals and play a role in all main biological and pathological processes, including the antivirus response [12, 15]. A large body of evidence has accumulated to date to indicate that the spectrum and level of microRNA expression depend on the functional state of the body with alteration in disease [16, 17]. Host cellular microRNAs can bind to the coding regions of genome of RNA viruses (e.g., HIV, hepatitis C virus, dengue virus, and influenza virus), thus exerting an antivirus effect $[2,12,14,18]$. Coronaviruses are also RNA viruses, and it cannot be excluded that microRNAs play a certain role together with many other factors that affect the risk of infection and the severity of the disease in the presence of various comorbidities.

SARS-CoV-2, which causes COVID-19, belongs to the betacoronavirus genus together with SARS-CoV (the causal agent of severe acute respiratory syn- 
drome) and MERS-CoV (the causal agent of Middle East respiratory syndrome). Outbursts of SARS-CoV and MERS-CoV infections occurred in 2002-2003 and 2012, respectively, but did not become pandemics. A phylogenetic analysis showed up to $79 \%$ similarity between the SARS-CoV-2 and SARS-CoV genomes and up to $50 \%$ similarity between the SARS-CoV-2 and MERS-CoV genomes [18, 19].

The SARS-CoV-2 is a positive-sense singlestranded RNA virus. The reference SARS-CoV-2 genome sequence deposited in the NCBI database (NC_045512.2) is approximately $29.9 \mathrm{~kb}$. The polyprotein genes ORFIa and ORF1b take in approximately two-thirds of the genome at its 5 ' end. Virus polyproteins are cleaved by proteases to produce nonstructural proteins (Nsps), which form a replicationtranscription complex. The other one-third of the SARS-CoV-2 genome harbors genes for structural proteins: a spike $(\mathrm{S})$ glycoprotein and membrane $(\mathrm{M})$, envelope (E), and nucleocapsid $(\mathrm{N})$ proteins. In addition, there are $5^{\prime}$ - and $3^{\prime}$-untranslated regions $\left(5^{\prime}\right.$-UTR and 3 '-UTR) in the SARS-CoV-2 genomic RNA [12, 19-22].

The spike glycoprotein (S protein) facilitates virus entry into the cell by binding with angiotensin-converting enzyme 2 (ACE2) [21]. The E protein forms the virus envelope and is involved in forming hydrophilic pores in cell membranes. The $\mathrm{M}$ protein determines the shape of the virus envelope and serves as a central organizer of coronavirus assembly [15, 23]. The $\mathrm{N}$ protein binds with the coronavirus genomic RNA and Nsp3, which is a nonstructural protein of the replication-transcription complex and plays a role in genome packaging in virions [20].

SARS-CoV-2 is an intracellular pathogen and utilizes host cell machinery for its function and replication. The efficiency of cell infection therefore depends on the functional state of the host cell (the ratio of the factors that are favorable or unfavorable for the process) and the possibility of quickly rearrange the molecular physiology of the cell and the total body to ensure virus reproduction and spreading (e.g., the possibility to evade the immune control of the body). MicroRNAs targeting the $S, M, N, E$, and ORFlab genes might suppress SARS-CoV-2 invasion into the cell and limit its replication, while lower levels of these microRNAs are favorable for cell infection and coronavirus replication [15]. Apart from human cell microRNAs, SARS-CoV-2 microRNAs might also play a role in the COVID-19 pathogenesis. The virus genome is potentially capable of producing microRNAs, which may be involved in epigenetic processes in infected cells [19]. In addition, human microRNAs may exert opposite effects to suppress infection or to act as a pro-viral factors [19, 24], and infection with SARS-CoV-2 changes the microRNA expression pattern in human cells [11]. A higher level of infection with SARS-CoV-2 compared with other coronavi- ruses makes it possible to assume that structural differences in specific regions of the coronavirus genome determine their effects on the risk of infection and the course of COVID-19. Structural features of the coronavirus genome may lead to the formation of various targets for human microRNAs and thus determine the disease scenarios in the presence of comorbidities that change the spectrum and expression levels of microRNAs.

The review considers various aspects of the role that microRNA may play in the pathogenesis of COVID-19. Our sources included the PubMed database and web resources with data on microRNA expression in human tissues and cells and microRNA roles in various human disorders (TissueAtlas [25], FANTOM5 [26], and Human MicroRNA Disease Database (HMDD) [16]).

\section{HUMAN microRNAs SPECIFIC FOR THE SARS-CoV-2 GENOME}

A PubMed search using the terms microRNA, miRNA, SARS-CoV-2, and COVID-19 in various combinations as queries yielded 16 publications (as of the end of 2020) that include information about microRNAs potentially capable of binding with the SARS-CoV-2 genome. The number of such microRNAs in different publications varied from three to more than 1000 because of the differences in databases, analytic tools, microRNA sample size, and SARS-CoV-2 genomic sequences used (Table S1, see Supplementary Materials at http://www.molecbio.ru/downloads/ 2022/1/supp_Kucher_rus.pdf). Certain microRNAs with targets in the SARS-CoV-2 genome are additionally capable of binding to the SARS-CoV and MERS$\mathrm{CoV}$ genomes and, in single cases, with the genomes of low pathogenic human coronaviruses that cause mild acute respiratory infections. These microRNAs were excluded from further analysis to identify the microRNAs that might determine the high pathogenicity for SARS-CoV-2 only. Another inclusion criterion used to select the SARS-CoV-2-specific microRNAs for the analysis was that a microRNA should be identified as specific in at least two publications (in order to reduce the probability of erroneously describing microRNA as potentially significant for cell infection). As a result, we selected 39 microRNAs that met the above criteria (Table 1).

It should be noted that different mature microRNAs originating from a common precursor may differ in the efficiency of binding to the genomes of different coronaviruses. For example, hsa-miR-195-3p binds only to the SARS-CoV-2 genome, while hsa-miR-195-5p additionally binds to the genomes of SARS-CoV and other coronaviruses $[2,34]$. The microRNA $(-3 p$ or $-5 p)$ that had been studied consequently received special attention whenever possible in considered studies. However, studies where the microRNA type ( $-3 p$ or $-5 p)$ had not been specified were also included in the anal- 
Table 1. Human microRNAs potentially capable of binding to various SARS-CoV-2 genes

\begin{tabular}{|c|c|c|c|}
\hline MicroRNA & MIMAT, number in miRBasê & Target gene & Source \\
\hline hsa-miR-16-2-3p & МIMAT0000069 & Not specified & {$[2,11]$} \\
\hline \multirow{2}{*}{ hsa-miR-23b-5p } & \multirow{2}{*}{ MIMAT0004587 } & ORF8 & {$[15,19]$} \\
\hline & & Not specified & {$[27]$} \\
\hline hsa-miR-34c-3p & MIMAT0004677 & Not specified & {$[2,14]$} \\
\hline \multirow{2}{*}{ hsa-miR-125a-3p } & \multirow{2}{*}{ MIMAT0004602 } & S protein gene & {$[19]$} \\
\hline & & Not specified & {$[2,11]$} \\
\hline \multirow{2}{*}{ hsa-miR-141-3p } & \multirow{2}{*}{ MIMAT0000432 } & ORFlab & [28] \\
\hline & & Not specified & {$[2,11]$} \\
\hline hsa-miR-142-3p & MIMAT0000434 & Not specified & {$[9,11]$} \\
\hline \multirow{2}{*}{ hsa-miR-193b-5p } & \multirow{2}{*}{ МIMAT0004767 } & M protein gene & {$[28]$} \\
\hline & & Not specified & {$[11]$} \\
\hline \multirow{2}{*}{ hsa-miR-195-3p } & \multirow{2}{*}{ MIMAT0004615 } & ORFlab, $S$ & {$[28]$} \\
\hline & & Not specified & {$[2,11,29]$} \\
\hline \multirow{3}{*}{ hsa-miR-197-5p } & \multirow{3}{*}{ MIMAT0022691 } & Nsp3, ORF1a & {$[30]$} \\
\hline & & ORFlab & {$[19]$} \\
\hline & & Not specified & {$[11]$} \\
\hline \multirow{2}{*}{ hsa-miR-203a-5p } & \multirow{2}{*}{ МIMAT0031890 } & S protein gene & [28] \\
\hline & & Not specified & {$[2,14]$} \\
\hline \multirow{3}{*}{ hsa-miR-208a-5p } & \multirow{3}{*}{ МIMAT0026474 } & $\mathrm{N}$ protein gene & {$[15,19]$} \\
\hline & & ORF $1 a b$ & [28] \\
\hline & & Not specified & {$[2]$} \\
\hline \multirow{2}{*}{ hsa-miR-208b-5p } & \multirow{2}{*}{ MIMAT0026474 } & ORFlab & [28] \\
\hline & & Not specified & {$[2,14]$} \\
\hline \multirow{3}{*}{ hsa-miR-325 } & \multirow{3}{*}{ MIMAT0000771 } & M protein gene & {$[15]$} \\
\hline & & ORF1ab & [28] \\
\hline & & Not specified & [2] \\
\hline \multirow{2}{*}{ hsa-miR-378c } & \multirow{2}{*}{ MIMAT0016847 } & ORFlab & [19] \\
\hline & & Not specified & {$[2,27,31]$} \\
\hline \multirow{3}{*}{ hsa-miR-548ag } & \multirow{3}{*}{ MIMAT0018969 } & ORFlab & {$[15,28]$} \\
\hline & & S protein gene & [15] \\
\hline & & Not specified & [2] \\
\hline \multirow{3}{*}{ hsa-miR-549a-3p } & \multirow{3}{*}{ MIMAT0003333 } & ORFlab & {$[19,28]$} \\
\hline & & ORF3a & {$[15]$} \\
\hline & & Not specified & {$[2]$} \\
\hline hsa_miR_605_5n & MUMAT0003273 & ORFlab & [28] \\
\hline nsa-mik-60s-sp & DHIVATUOUSZT3 & Not specified & {$[2,28]$} \\
\hline hsa-miR-628-3n & MIMAT0004809 & ORF $1 a b$ & {$[19,28]$} \\
\hline $118 d-1111-0<0-5 p$ & & Not specified & [2] \\
\hline hen_miR_668_3n & MUMAT0003881 & 5'-UTR & {$[18]$} \\
\hline nsa-mik-obs-3p & 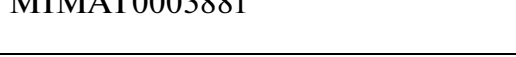 & Not specified & {$[2,14]$} \\
\hline hsa-miR-1246 & MIMAT0005898 & ORF3a & [15] \\
\hline nsa-mIK-1 & 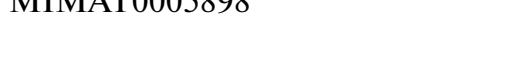 & Not specified & {$[11]$} \\
\hline
\end{tabular}


Table 1. (Contd.)

\begin{tabular}{|c|c|c|c|}
\hline MicroRNA & MIMAT, number in miRBase & Target gene & Source \\
\hline \multirow{3}{*}{ hsa-miR-1293 } & \multirow{3}{*}{ MIMAT0005883 } & 3'-UTR & {$[22]$} \\
\hline & & ORF1ab & [28] \\
\hline & & Not specified & {$[2,11]$} \\
\hline \multirow{2}{*}{ hsa-miR-1910-3p } & \multirow{2}{*}{ MIMAT0026917 } & ORF1ab/ORF7a/N protein gene & {$[15]$} \\
\hline & & Not specified & {$[11]$} \\
\hline hsa-miR-2392 & MIMAT0019043 & ORF8 & {$[15,19]$} \\
\hline \multirow{2}{*}{ hsa-miR-3120-5p } & \multirow{2}{*}{ MIMAT0019198 } & ORFlab & [19] \\
\hline & & Not specified & {$[31]$} \\
\hline \multirow{2}{*}{ hsa-miR-3132 } & \multirow{2}{*}{ MIMAT0014997 } & ORF3a & {$[19]$} \\
\hline & & Not specified & [11] \\
\hline hsa-miR-3135b & MIMAT0018985 & ORF7a & {$[15,19]$} \\
\hline \multirow{2}{*}{ hsa-miR-3155a } & \multirow{2}{*}{ MIMAT0015029 } & $\mathrm{N}$ protein gene & {$[15,19]$} \\
\hline & & Not specified & {$[2]$} \\
\hline \multirow{4}{*}{ hsa-miR-3190-3p } & \multirow{4}{*}{ MIMAT0022839 } & ORF1ab & {$[15,19]$} \\
\hline & & ORF8 & {$[15]$} \\
\hline & & \begin{tabular}{|l|} 
S protein gene \\
\end{tabular} & [28] \\
\hline & & Not specified & [2] \\
\hline \multirow{2}{*}{ hsa-miR-3914 } & \multirow{2}{*}{ MIMAT0018188 } & ORF1ab & {$[19,28]$} \\
\hline & & Not specified & {$[31]$} \\
\hline \multirow{2}{*}{ hsa-miR-4510 } & \multirow{2}{*}{ МIMAT0019047 } & ORF3a & {$[15]$} \\
\hline & & S protein gene & [19] \\
\hline \multirow{3}{*}{ hsa-miR-4684-3p } & \multirow{3}{*}{ MIMAT0019770 } & ORF7a & [19] \\
\hline & & $\mathrm{N}$ protein gene & [28] \\
\hline & & Not specified & [2] \\
\hline \multirow{2}{*}{ hsa-miR-5087 } & \multirow{2}{*}{ МIMАТ0021079 } & ORF1ab & [28] \\
\hline & & Not specified & {$[2,32]$} \\
\hline \multirow{3}{*}{ hsa-miR-5590-3p } & \multirow{3}{*}{ MIMAT0022300 } & ORF7a & {$[15]$} \\
\hline & & ORF1ab & {$[28]$} \\
\hline & & Not specified & {$[2]$} \\
\hline \multirow{2}{*}{ hsa-miR-6736-5p } & \multirow{2}{*}{ MIMAT0027373 } & ORF1ab & [19] \\
\hline & & Not specified & [11] \\
\hline \multirow{3}{*}{ hsa-miR-6741-5p } & \multirow{3}{*}{ MIMAT0027383 } & $\mathrm{N}$ protein gene & {$[15]$} \\
\hline & & ORF1ab & [19] \\
\hline & & Not specified & [29] \\
\hline hsa-miR-6751-5p & MIMAT0027402 & ORF3a & {$[15,19]$} \\
\hline & & ORFlab & [19] \\
\hline hsa-miR-6837-3p & MIMAT0027577 & 5'-UTR & {$[18]$} \\
\hline & & Not specified & [2] \\
\hline hsa-miR_8066 & MIMAT0030993 & $\mathrm{N}$ protein gene & {$[15,19]$} \\
\hline hsa-mik- & МIMАТ0030993 & Not specified & {$[12,31]$} \\
\hline hso-miR - 12119 & MIMAT 0040013 & ORF1ab & [15] \\
\hline $1 \mathrm{~s} a-1 m 12-1219$ & МНIMAI U049013 & $\mathrm{N}$ protein gene & [19] \\
\hline
\end{tabular}

* Data were retrieved from miRBase [33]. 
ysis (microRNAs are hereafter designated as in the respective original articles).

Regions of the SARS-CoV-2 genome differ in the number of microRNAs capable of binding to them. The greatest number of microRNAs (22) was described for ORF1ab and the genes coding for the $\mathrm{S}$ and $\mathrm{N}$ proteins (Table 1 ). This generally agrees with the sizes of the respective genes (although the S protein-coding gene is several times larger than the $\mathrm{N}$ protein-coding gene) [35]. One to three SARS-CoV-2 genes were described as microRNA targets, but the localization of microRNA targets was not specified in several cases (Table 1). It is unknown now whether the efficiency of infection is affected by what particular SARS-CoV-2 gene is targeted by microRNAs of the host cell, although the presence of several targets for different microRNAs can be assumed to facilitate better protection from virus infection. This is related to the fact that the SARS-CoV-2 genome can acquire new mutations, which may lead to a loss of a target or generate a new target for the same microRNA or produce targets for other microRNAs, which had no target in the coronavirus genome earlier. In particular, this situation was observed when the binding profiles of 24 microRNAs were compared for 67 different SARS-CoV-2 genomes found in 24 countries [19]. The set contained four microRNAs included in our analysis: hsa-miR-23b-5p, -378c, -549a-3p, and -12119; their targets were lost in 2, 1, 11, and 2 SARS-CoV-2 genomes, respectively. It is noteworthy that certain microRNA clusters based on the profiles of binding to the SARS-CoV-2 genome proved associated with higher mortality from COVID-19 in the countries where they had been revealed [19], indicating that both host microRNAs and features of the coronavirus genome are of importance for the COVID-19 clinical course. In this context, ORF1ab is the most vulnerable SARS-CoV-2 gene because the greatest number of microRNAs are capable of binding to it. The greatest protective effect can be expected for hsa-miR-1910-3p and hsa-miR-3190-3p, which target at least three genes each in the coronavirus genome (Table 1).

The potential to protect the host cell depends not only on the presence of targets in the SARS-CoV-2 genome, but also on the microRNA expression level. Protection against SARS-CoV-2 may be affected by the microRNA expression level in cells of the organs that the virus uses to enter the body, while the risk of complications may be affected in other organs. As is well known, microRNA expression is characterized by tissue and cell specificity, sensitivity to environmental factors, and dependence on the functional state of the body. We therefore analyzed the data on microRNA expression in organs (and cells) of healthy individuals; the data were downloaded from online available databases (TissueAtlas [25] and FANTOM5 [26]). Then we summarized the data on how the expression levels of these microRNAs change in certain diseases that are of importance for the clinical course of COVID-19 (PubMed, Human MicroRNA Disease Database [16]).

EXPRESSION OF microRNAs POTENTIALLY CAPABLE OF BINDING TO THE SARS-CoV-2 GENOME IN HUMAN CELLS AND TISSUES

To choose the tissues, organs, and cells for analysis of the microRNAs that are potentially capable of binding to the SARS-CoV-2 genome, we considered the results of epidemiological studies that described their sensitivity to the coronavirus or the rate at which they are affected in COVID-19 [3-8]. In total, 16 tissues (Fig. 1) and 20 cell types from various organs (Fig. 2) were analyzed.

Scarce data are available for microRNA expression levels in tissues and organs of healthy humans: samples from only one individual who died naturally are described in TissueAtlas [25]. Expression of 22 of the 39 microRNAs under study was detected in the lung, various regions of the brain, organs of the digestive tract, the heart, arteries, the kidney, and the prostate (16 organs in total) (Fig. 1). Three microRNA clusters were identified. One included five microRNAs that are expressed to relatively high levels in tissues of all organs (hsa-miR-197-5p, -1246, -3135b, -2392, and -125a-3p); the second cluster included seven microRNAs with a moderate expression level (hsa-miR-3132, -605-5p, $-142-3 p,-193 b-5 p,-3190-3 p,-195-3 p$, and $-141-3 p)$; and the third included 12 microRNAs with a low expression level. Expression was demonstrated for only one of the two microRNAs that have the greatest number of targets in the SARS-CoV-2 genome, hsamiR-3190-3p (Table 1), but its expression level is relatively low (lower than average) (Fig. 1). Tissue specificity of microRNA expression is also observed within the clusters. Depending on the microRNA expression level, the tissues also form three clusters (Fig. 1). In the lung hsa-miR-197-5p, -1246 , and $-3135 b$ have the highest expression levels $\left(>10 \log _{2}\right.$ (quantile-normalized expression (QNE)), and these microRNAs are possible to consider as potentially significant for limiting SARS-CoV-2 infection.

Because tissues have a heterogeneous cell composition, at the second step we analyze the expression specifics of the 39 selected microRNAs in various cell types, retrieving data from FANTOM5 [26]. In particular, epithelial cells of various organs, blood cells, and other cell types were considered (Fig. 2). Data on expression in the cell types chosen for the analysis were available for 36 out of the 39 microRNAs. Expression of 11 out of the 36 microRNAs was not detected in the cell types under study. These are hsamiR-3135b, -8066, -6741-5p, -6736-5p, -5590-3p, $-5087,-4684-3 p,-3914,-3132,-208 a-5 p$, and $-208 b-5 p$; data on these microRNAs are not shown in Fig. 2. Expression of six other microRNAs (hsa-miR-548ag, $-3120-5 p,-4510,-1246,-2392$, and $-6751-5 p)$ is 


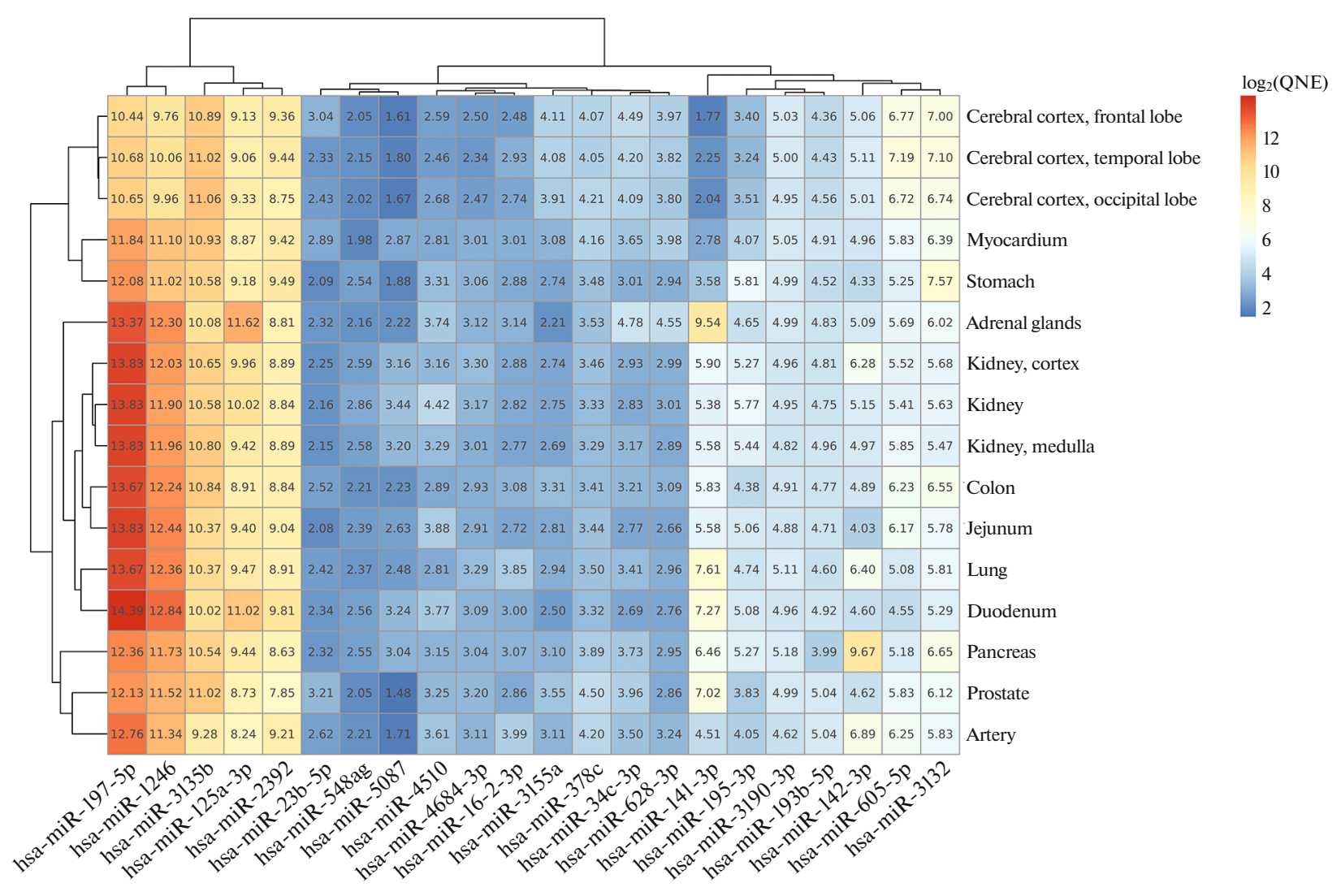

Fig. 1. Heatmap that shows expression of microRNAs potentially capable of binding to the SARS-CoV-2 genome in tissues of various human organs (according to TissueAtlas [25]). Expression levels are shown as logarithmic quartile-normalized expression $\left(\log _{2}(\mathrm{QNE})\right)$.

extremely low $\left(<1.0 \log _{2}(\mathrm{CPM})\right)$ in single types of cells. The remaining 19 microRNAs are expressed at higher levels $\left(>1.0 \log _{2}(\mathrm{CPM})\right)$, which vary among different cell types. The microRNA hsa-miR-16-2-3p was the only microRNA that is expressed at a moderate (and much the same) level in all cell types under discussion (5.71-7.91 $\left.\log _{2}(\mathrm{CPM})\right)$. None of the microRNAs that have at least three targets in the SARS-CoV-2 genome (Table 1) belongs to the category of microRNAs highly expressed in the cell types under study (Fig. 2).

Expression levels of certain microRNAs are specific for different cell types: hsa-miR-142-3p is highly expressed (>10 $\left.\log _{2}(\mathrm{CPM})\right)$ in blood cells and shows only minor, if any, expression in the other cell types; hsa-miR-141-3p is expressed at a high level in epithelial cells of the respiratory and digestive tracts and prostate and B cells, a moderate level in other blood cells, and a low level in all other cell types. The hsamiR-125a-3p expression level is low in blood cells and moderate in the other cell types. Expression levels of the other microRNAs similarly depend on the cell type, but are generally low $\left(<4.0 \log _{2}(\mathrm{CPM})\right.$ in the majority of cases). Based on the above data on microRNA expression in various cell types of healthy subjects (Fig. 2), it is possible to conclude that the most promising candidates for a role in SARS-CoV-2 infection and the clinical course of COVID-19 are hsa-miR-16-2-3p, -125a-3p, -141-3p, -142-3p, and, to a lesser extent, hsa-miR-378, -628-3p, -1293, -23b$5 p,-34 c-3 p,-193 b-5 p,-668-3 p$, and $-195-3 p$. These microRNAs have targets in the SARS-CoV-2 genome, and their high expression can be expected to decrease the risk of infection or severe COVID-19. The hsamiR-141-3p holds a special place in the set because its expression is high in epithelial cells of lower airways and the digestive tract, which provide the first barrier to SARS-CoV-2 infection.

\section{EXPRESSION OF microRNAS POTENTIALLY CAPABLE OF BINDING TO THE SARS-CoV-2 GENOME IN VARIOUS DISEASES}

Because the microRNA expression level depends on the functional state of the body and may change in pathology [16, 17] and because certain diseases and comorbid conditions act as a risk factor for severe COVID-19 $[3,4,36]$, changes in expression profiles in various diseases were analyzed for the microRNAs specific for SARS-CoV-2. Relevant information was available for 16 microRNAs (Table 2). Unfortunately, 


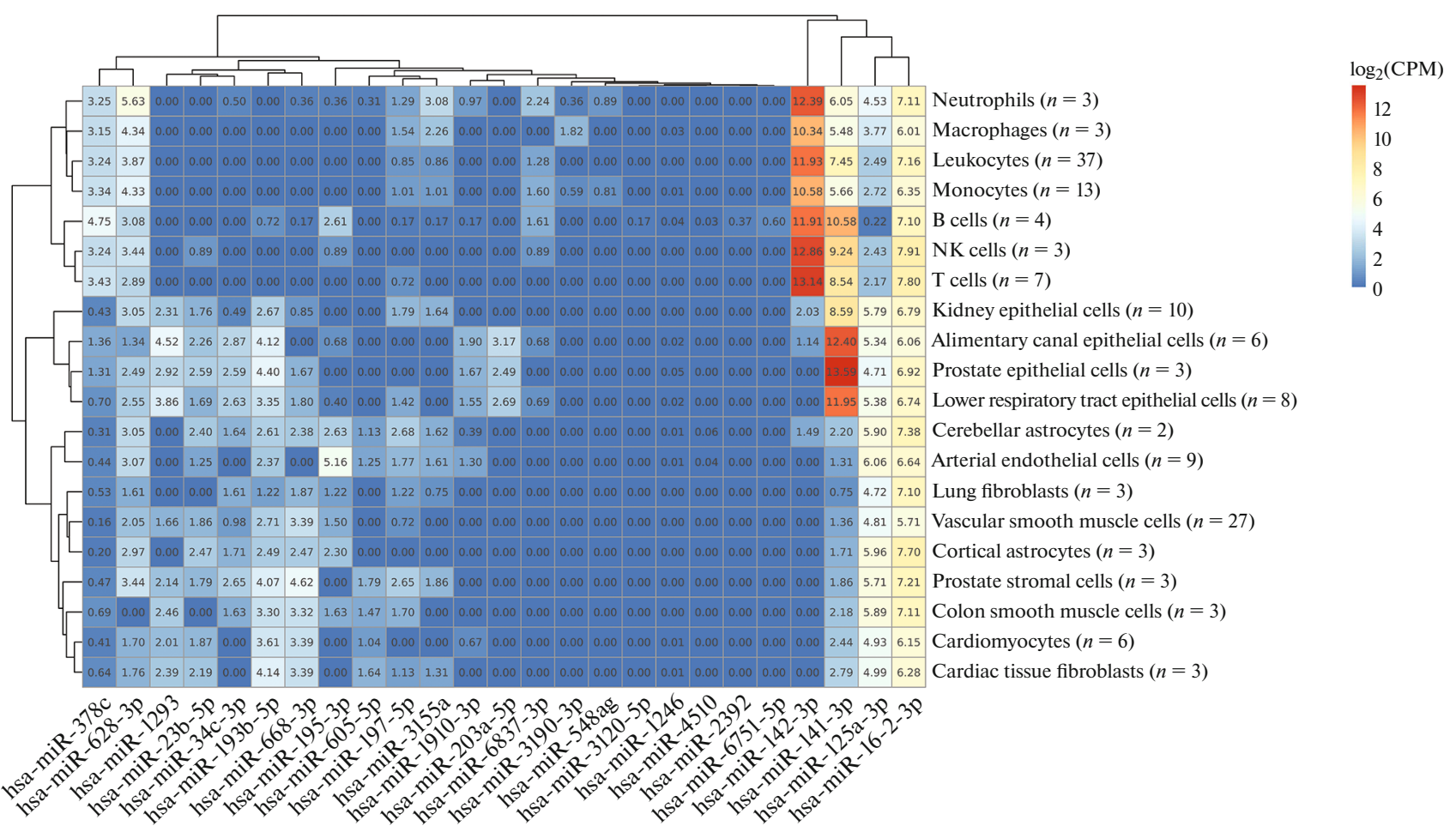

Fig. 2. Heatmap that shows expression of microRNAs potentially capable of binding to the SARS-CoV-2 genome in primary cultures of human cells (according to FANTOM5 [26]). Normalized expression levels are shown as $\log _{2}(\mathrm{CPM})$, where CPM is counts per million; $n$ is the number of samples with data available from FANTOM5.

the set did not include the microRNAs that were identified above as potentially significant for risk of SARSCoV-2 infection and the clinical course of COVID-19, such as hsa-miR-1910-3p, hsa-miR-3190-3p (each having at least three targets in the SARS-CoV-2 genome (Table 1)), and hsa-miR-3135b (high-level expression in various organs (Fig. 1)).

Based on HMDD data [16], the majority of microRNAs specific for SARS-CoV-2 show changes in concentration in the blood and affected organs in various diseases, including respiratory and cardiovascular disorders (especially hypertension), diabetes mellitus and its complications, autoimmune disorders (Table 2), etc. Unfortunately, it was not indicated in many studies which strand gives origin to a regulated microRNA; and microRNA families, rather than individual microRNAs, were considered in some studies. However, they were not excluded from our analysis.

Respiratory disorders associated with changes in expression of human microRNAs specific for the SARS-CoV-2 genome are of particular interest. Changes in expression of seven SARS-CoV-2-specific human microRNAs were observed in COPD, pulmonary hypertension, bronchial asthma, and bacterial pneumonia (Table 2). Three of these microRNAs (hsa-miR-125a-3p, -197-5p, and -1246) belong to the category of microRNAs highly expressed in various organs, including the lung (Fig. 1).
The levels of SARS-CoV-2-specific microRNAs were assayed in lung tissue or blood samples from patients or animal (mouse) models with various disorders of the respiratory system. Downregulation of various microRNAs was observed in lung disorders in the majority of studies. An increase in SARS-CoV-2-specific microRNAs in human lung tissue was not observed in the respiratory disorders under study (Table 2).

A decrease in hsa-miR-203 was detected in bronchial epithelial cells in bronchial asthma [43] and in lung tissues of smokers with COPD as compared with healthy individuals, both smokers and nonsmokers [40]. However, the hsa-miR-203 level in the blood of the same COPD patients was higher than in nonsmokers, but somewhat (nonsignificantly) lower than in healthy smokers [40]. It is possible to assume that smoking is an important factor that affects the hsamiR-203 expression level and that higher levels of this microRNA in smokers are responsible for the fact that smoking is not identified as a risk factor for COVID-19 in some studies [77].

The hsa-miR-203 normally has a low level of expression in respiratory epithelial cells (Fig. 2), and its lower content in lung tissue in COPD may act as an unfavorable factor with respect to COVID-19. However, higher levels of hsa-miR-203 in white blood cells may prevent the infection process from spreading out- 
Table 2. Expression regulation in various diseases for microRNAs that are potentially capable of binding to the SARS-CoV-2 genome

\begin{tabular}{|c|c|c|c|c|}
\hline Pathology & MicroRNA source & MicroRNA & Change in microRNA level & Reference \\
\hline \multicolumn{5}{|c|}{ Respiratory disorders } \\
\hline \multirow[t]{3}{*}{ COPD } & Pulmonary artery & $\operatorname{miR}-197$ & $\downarrow$ as compared with nonsmokers & {$[37]$} \\
\hline & Blood plasma & miR-628-3p & $\begin{array}{l}\downarrow \text { as compared with smokers and } \\
\text { nonsmokers }\end{array}$ & {$[38]$} \\
\hline & Blood serum & miR-1246 & $\begin{array}{l}\downarrow \text { in patients after } 10 \text { years; emphy- } \\
\text { sema in } 75 \% \text { of cases }\end{array}$ & {$[39]$} \\
\hline \multirow[t]{2}{*}{ COPD, smokers } & Blood & $\operatorname{miR}-203$ & $\begin{array}{l}\uparrow \text { as compared with nonsmokers, but } \\
\text { lower (nonsignificantly) than in } \\
\text { smokers }\end{array}$ & \multirow[t]{2}{*}{ [40] } \\
\hline & Lung tissue & $\operatorname{miR}-203$ & $\begin{array}{l}\downarrow \text { as compared with smokers and } \\
\text { nonsmokers }\end{array}$ & \\
\hline \multirow[t]{2}{*}{ Pulmonary hypertension } & \multirow[t]{2}{*}{ White blood cells } & $\mathrm{miR}-1246$ & $\downarrow$ & \multirow[t]{3}{*}[41]{} \\
\hline & & $\operatorname{miR}-23 b$ & $\uparrow$ & \\
\hline $\begin{array}{l}\text { Severe pulmonary hyperten- } \\
\text { sion }\end{array}$ & White blood cells & miR-208b & $\begin{array}{l}\uparrow \text { as compared with control and } \\
\text { moderate pulmonary hypertension }\end{array}$ & \\
\hline \multirow{2}{*}{$\begin{array}{l}\text { Pulmonary hypertension } \\
\text { in mice }\end{array}$} & Hypoxic lung tissue & miR-125a & $\uparrow$ & \multirow[t]{2}{*}[42]{} \\
\hline & Circulating microRNAs & miR-125a & $\downarrow$ & \\
\hline Bronchial asthma & Bronchial epithelium & miR-203 & $\downarrow$ & {$[43]$} \\
\hline $\begin{array}{l}\text { LPS-induced pneumonia } \\
\text { in mice }\end{array}$ & Lung tissue & $\mathrm{miR}-203$ & $\begin{array}{l}\uparrow \text { increases reaches maximum within } \\
5 \text { days }\end{array}$ & {$[44]$} \\
\hline \multicolumn{5}{|c|}{ Cardiovascular disorders } \\
\hline Hypertension and heart failure & $\begin{array}{l}\text { Peripheral blood mono- } \\
\text { nuclear cells }\end{array}$ & miR-208b & $\begin{array}{l}\uparrow \text { as compared with hypertension } \\
\text { without heart failure }\end{array}$ & {$[45]$} \\
\hline $\begin{array}{l}\text { Hypertension with left ventric- } \\
\text { ular hypertrophy }\end{array}$ & Blood plasma & $\operatorname{miR}-208$ & $\uparrow$ & {$[46]$} \\
\hline $\begin{array}{l}\text { Hypertension, including that } \\
\text { with left ventricular hypertro- } \\
\text { phy }\end{array}$ & $\begin{array}{l}\text { Peripheral blood mono- } \\
\text { nuclear cells }\end{array}$ & $\operatorname{miR}-208$ & $\uparrow$ & {$[17,47]$} \\
\hline Hypertensive nephrosclerosis & Kidney tissue & $\operatorname{miR}-141$ & $\uparrow$ & {$[48]$} \\
\hline Heart failure, stage C or D & Blood serum & miR-197-5p & $\uparrow$ & [49] \\
\hline Heart failure & Blood plasma & miR-193b-5p & $\downarrow$ & {$[50]$} \\
\hline $\begin{array}{l}\text { Heart failure with reduced left } \\
\text { ventricular ejection fraction }\end{array}$ & Blood plasma & miR-193b-5p & $\downarrow$ & {$[50]$} \\
\hline Ischemia during surgery & Right atrial myocardium & miR-195 & $\downarrow$ & {$[51]$} \\
\hline $\begin{array}{l}\text { Ischemic and nonischemic } \\
\text { heart failure }\end{array}$ & Blood plasma & $\operatorname{miR}-195-3 p$ & $\uparrow$ & {$[52]$} \\
\hline Coronary artery disease & Blood plasma & miR-208a & $\uparrow$ & {$[53]$} \\
\hline $\begin{array}{l}\text { Obstructive coronary artery } \\
\text { disease }\end{array}$ & Blood plasma & $\mathrm{miR}-3135 b$ & $\uparrow$ & {$[54]$} \\
\hline \multirow{2}{*}{$\begin{array}{l}\text { Left ventricular myocardial } \\
\text { hypertrophy, mice }\end{array}$} & \multirow{2}{*}{$\begin{array}{l}\text { Left ventricular myocar- } \\
\text { dium }\end{array}$} & $\operatorname{miR}-23$ & $\uparrow$ & {$[55]$} \\
\hline & & miR-195 & $\uparrow$ & \\
\hline $\begin{array}{l}\text { Left ventricular myocardial } \\
\text { hypertrophy }\end{array}$ & $\begin{array}{l}\text { Left ventricular myocar- } \\
\text { dium }\end{array}$ & miR-195 & $\uparrow$ & {$[56]$} \\
\hline $\begin{array}{l}\text { Hypertrophic cardiomyopa- } \\
\text { thy in cats }\end{array}$ & Blood serum & $\operatorname{miR}-1246$ & $\uparrow$ & [57] \\
\hline
\end{tabular}


Table 2. (Contd.)

\begin{tabular}{|c|c|c|c|c|}
\hline Pathology & MicroRNA source & MicroRNA & Change in microRNA level & Reference \\
\hline Atrial fibrillation & Atrial myocardium & miR-208a & $\downarrow$ as compared with sinus rhythm & [58] \\
\hline Chronic atrial fibrillation & Myocardium & $\mathrm{miR}-208 \mathrm{~b}$ & $\uparrow$ & [59] \\
\hline Myocardial infarction & Blood plasma & miR-195-3p & $\begin{array}{l}\uparrow \text { after } 8 \mathrm{~h} \text { (maximal value) and } 12 \mathrm{~h} \\
\text { after infarction }\end{array}$ & [60] \\
\hline Myocardial infarction & Myocardium & miR-208 & $\uparrow$ & [61] \\
\hline Angina pectoris & Blood plasma & miR-208a & $\begin{array}{l}\uparrow \text { as compared with control and } \\
\text { myocardial infarction }\end{array}$ & [62] \\
\hline $\begin{array}{l}\text { Myocardial diastolic dysfunc- } \\
\text { tion }\end{array}$ & Blood plasma & $\operatorname{miR}-1246$ & $\uparrow$ & [63] \\
\hline $\begin{array}{l}\text { Stable compensated dilated } \\
\text { cardiomyopathy (systolic }+ \\
\text { diastolic dysfunction); decom- } \\
\text { pensated congestive heart fail- } \\
\text { ure secondary to dilated } \\
\text { cardiomyopathy }\end{array}$ & Blood plasma & miR-142-3p & $\downarrow$ & [63] \\
\hline $\begin{array}{l}\text { Coronary artery aneurysm in } \\
\text { children with Kawasaki disease }\end{array}$ & Blood serum exosomes & miR-1246 & $\begin{array}{l}\downarrow \text { as compared with healthy or infec- } \\
\text { tion with Epstein-Barr or Aujeszky } \\
\text { disease virus }\end{array}$ & [64] \\
\hline $\begin{array}{l}\text { Persons with high risk of car- } \\
\text { diovascular disorders }\end{array}$ & Blood serum & miR-23b & $\uparrow$ & [65] \\
\hline
\end{tabular}

\begin{tabular}{l|l|l|l|l}
\hline Type 2 diabetes mellitus & Blood plasma & miR-197 & $\downarrow$ & {$[66]$} \\
\hline Type 1 or 2 diabetes mellitus & Peripheral blood & miR-23b & $\downarrow$ & {$[67]$} \\
\hline Prediabetes & Blood serum & miR-193b & $\uparrow$ & {$[68]$} \\
\hline Diabetic nephropathy & Blood serum exosomes & miR-1246 & $\begin{array}{l}\uparrow \text { as compared with control and dia- } \\
\text { betes without nephropathy }\end{array}$ & {$[69]$} \\
\hline $\begin{array}{l}\text { Ischemic diabetic cardiomy- } \\
\text { opathy }\end{array}$ & $\begin{array}{l}\text { Left ventricular myocar- } \\
\text { dium }\end{array}$ & miR-23b & $\downarrow$ & {$[70]$} \\
$\begin{array}{l}\text { Proliferative diabetic reti- } \\
\text { nopathy }\end{array}$ & Vitreous body & miR-142-3p & $\uparrow$ & {$[71]$} \\
\hline
\end{tabular}

\begin{tabular}{l|l|l|l|l}
\hline \multicolumn{5}{l}{ Autoimmune disorders } \\
\hline Ulcerative colitis, active phase & Inflamed colon & miR-378c & $\begin{array}{l}\uparrow \text { during anti-TNF therapy com- } \\
\text { pared with other therapies }\end{array}$ & [72] \\
\hline Systemic lupus erythematosus & Kidney tissue & miR-23b & $\downarrow$ & {$[73]$} \\
\hline Rheumatoid arthritis & Joint synovial tissue & miR-23b & $\downarrow$ & {$[73]$} \\
\hline $\begin{array}{l}\text { Crohn's disease, ulcerative } \\
\text { colitis, active phase; rheuma- } \\
\text { toid arthritis }\end{array}$ & Blood serum & miR-1246 & $\begin{array}{l}\uparrow \text { as compared with control and inac- } \\
\text { tive form of the disease (for Crohn's } \\
\text { disease and ulcerative colitis) }\end{array}$ & {$[74]$} \\
\hline $\begin{array}{l}\text { Cutaneous lupus erythemato- } \\
\text { sus, subacute and discoid } \\
\text { lesions }\end{array}$ & Blood serum & miR-1246 & $\downarrow$ & {$[75]$} \\
\hline $\begin{array}{l}\text { Cutaneous lupus erythemato- } \\
\text { sus, subacute lesion }\end{array}$ & Blood serum & miR-23b & $\downarrow$ & \begin{tabular}{l}
$\downarrow$ \\
\hline $\begin{array}{l}\text { Graves' disease } \\
\text { nuclear cells }\end{array}$
\end{tabular} \\
\hline
\end{tabular}

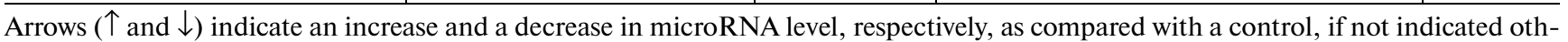
erwise. 
side the lung. A lower level of hsa-miR-203 in the bronchial epithelium in asthma must also favor COVID-19 development (Table 2), but asthma is not considered to be a risk factor for COVID-19 [78, 79].

An increase in miR-203 in lung tissue was observed in animal models with lipopolysaccharide (LPS)-induced pneumonia [44]. Higher levels of hsa-miR-203 were detected in nasal mucosa samples from newborns infected with the respiratory syncytial virus [80]. It should be noted that concomitant infections with bacteria, viruses, or fungi are detected in the overwhelming majority of COVID-19 patients [81].

It is of interest that a lower serum level of hsa-miR1246 correlates with a longer COPD in patients and that pulmonary emphysema develops in three-fourths of the patients with low levels of this microRNA [39]. A decrease in hsa-miR-1246 in white blood cells was additionally observed in pulmonary hypertension [41]. The hsa-miR-1246 belongs to the category of microRNAs expressed at a high levels in various organs (Fig. 1), but its level in lung tissue is decreased in smokers. Note that hsa-miR-1246 regulates expression of ACE2, which codes one of the key receptors for SARS-CoV-2 $[21,82]$. Lower levels of hsa-miR-1246 may consequently favor SARS-CoV-2 infection in the lung and other organs by increasing $A C E 2$ expression.

The opposite effects that smoking exerts on the levels of SARS-CoV-2-specific human microRNAs (in particular, miR-1246 and miR-203) makes it difficult to establish the factor that regulates expression of different microRNAs (an exogenous factor or pathology) and, therefore, to identify the conditions that determine the risk of infection and the course of COVID-19. Moreover, different changes in microRNA expression may occur in different tissues in the same disorder (Table 2), as is the case with miR-125a, which increased in lung tissue and decreased in the blood in mice with pulmonary hypertension [42].

Thus, several SARS-CoV-2-specific microRNAs are regulated in respiratory disorders. Opposite changes in expression may be observed, a microRNA may be expressed at a different levels in different tissues (the lung and the blood), and expression levels may be modified by environmental factors (in particular, smoking and bacterial infection).

Changes that arise in the levels of SARS-CoV-2specific human microRNAs in other disorders may affect the risk of COVID-19 complications. Blood cells and exosomes were most often tested for expression levels of these biomolecules in various disorders, while affected organs were examined less frequently (Table 2).

Cardiovascular disorders are thought to be a risk factor for COVID-19 complications [3, 4, 83]. However, expression of SARS-CoV-2-specific microRNAs was found to increase in the majority of studies (Table 2) and should exert a protective effect against COVID-19.
The following considerations are important to take into account here.

First, an increase in SARS-CoV-2-specific human microRNAs often reflects the severity of a pathological process (Table 2). For example, the serum hsamiR-197-5p level increases in heart failure and correlates with myocardial fibrosis and adverse cardiac events in patients [49]. In other words, higher levels of certain microRNAs reflect the severity or advanced stage of the main disease, and this may provide a more significant prognostic factor of a health condition or an outcome of the concomitant disease and COVID-19 than the possibility to block the spreading of SARS$\mathrm{CoV}-2$ in the body.

Second, the respiratory system acts as a site of SARS-CoV-2 entry, and the gene expression pattern (including microRNA genes) may change in the lung and other organs after infection [9, 84].

Third, only three microRNAs that showed changes in expression in cardiovascular disorders (hsa-miR197-5p, -3135 , and -1246 ) belong to the category of highly expressed microRNAs, and one (hsa-miR-141) is expressed to a moderate level (Figs. 1, 2). The microRNA expression level may be of importance for suppression of virus spreading in the body at the viremia stage, and the process certainly depends on the virus load in the total body.

Only five microRNAs were found to decrease in expression in cardiovascular disorders (Table 2): hsamiR-193b-5p decreases in the blood plasma in heart failure [50], hsa-miR-195 decreases in the myocardium in ischemia during surgery [51], hsa-miR-208a decreases in the myocardium in atrial fibrillation [58], hsa-miR-142-3p decreases in the blood plasma in systolic and diastolic dysfunction secondary to dilated cardiomyopathy [63], and hsa-miR-1246 decreases in blood serum exosomes in coronary artery aneurysm in children with Kawasaki disease [64].

It is of interest that multisystem inflammatory syndrome is sometimes observed in children and adults infected with SARS-CoV-2 and is similar in clinical picture to Kawasaki disease [85-87]. When the level of hsa-miR-1246 decreases as a result of its binding to the SARS-CoV-2 genome, the decrease may not only promote coronavirus entry into the cell by upregulating expression of the virus receptor (ACE2), but also modulate the other metabolic pathways that determine the pathogenesis of Kawasaki-like multisystem inflammation and certain autoimmune disorders, which are detected at an increasing rate in epidemiological studies [88]. The hsa-miR-142-3p level in the whole blood is additionally reduced in patients with moderate or severe COVID-19. The hsa-miR-142-3p is thought to provide a biomarker of severe COVID-19 and a potential therapeutic target because its downregulation promotes the inflammatory process [9].

Type 2 diabetes mellitus. Changes in expression of SARS-CoV-2-specific microRNAs were observed in 
other disorders associated with a higher risk of severe COVID-19 (Table 2), including diabetes mellitus, liver disorders, etc. [89, 90]. For example, patients with type 2 diabetes mellitus have lower blood plasma levels of hsa-miR-197 [66] and hsa-miR-23b [67]. The level of the latter microRNA in the left ventricular myocardium decreases in ischemic diabetic cardiomyopathy [70] (Table 2), and its decreasing is possible to consider as a risk factor for COVID-19 complications and agrees with epidemiological observations $[3,4,36]$.

Higher expression in the blood serum was observed for hsa-miR-1246 in diabetic nephropathy [69] and hsa-miR-193b in prediabetes [68]. In the former case, a high microRNA level and microRNA sequestration via binding to the SARS-CoV-2 genome cannot exert a protective effect because a decrease in hsa-miR1246 increases the ACE2 level and thus favors virus entry into the cell, as mentioned above. As for hsamiR-193b, an increase in its expression was observed in prediabetes, but not in diabetes [68]. Second, the increase was unstable, and factors that normalize metabolic parameters (e.g., regular physical exercise) returned the microRNA content to its initial level in patients with prediabetes and in mice with glucose intolerance. The finding indicates again that various factors can modify the microRNA level. In total, it is possible to assume that low levels of hsa-miR-197 (which is normally expressed at a high level in various organs, Fig. 1) and hsa-miR-23b (which is normally expressed at a low level, Fig. 1) in type 2 diabetes mellitus may facilitate COVID-19 complications.

Autoimmune disorders and microRNA regulation in these conditions are of interest to consider as factors that may affect the risk of SARS-CoV-2 infection and determine the clinical course of COVID-19 and the development of autoimmune disorders as its complications. The pathophysiology of intestinal autoimmune disorders (such as Crohn's disease and ulcerative colitis) and the presence of SARS-CoV-2 in intestinal cells create the conditions that promote SARS-CoV-2 infection. However, there is no evidence that COVID-19 affects patients with inflammatory disorders of the intestine more often than the general population, the fact being possibly related to the specifics of therapy for these disorders [91]. Moreover, drugs used to treat autoimmune disorders are considered as a means to treat COVID-19 [92]. Yet there is no consensus of option about the risk of COVID-19 complications in patients with autoimmune disorders.

A lower risk of COVID-19 and its complications is possible to assume for certain treatments used in autoimmune disorders because expression of SARS-CoV-2specific hsa-miR-378c in inflamed colon tissues of ulcerative colitis patients who receive TNF inhibitors is higher than in patients who receive other treatments and in healthy individuals [72]. Elevated blood serum levels of hsa-miR-1246 were additionally observed in patients with active ulcerative colitis, Crohn's disease, and rheumatoid arthritis [74], and hsa-miR-23b-5p is increased on blood mononuclear cells of patients with Graves' disease in remission as compared with patients who have a severe course of the disease [76]. It is possible that the severity of the disease or the extent of its compensation determine the risk of severe COVID-19 in patients with autoimmune disorders.

On the other hand, the SARS-CoV-2-specific microRNAs hsa-miR-1246 and hsa-miR-23b show decreased blood serum contents in patients with various forms of systemic lupus erythematosus [75]. Autoimmune disorders, including systemic lupus erythematosus and Guillain-Barre syndrome, were found to develop after COVID-19 in a number of patients [93]. Thus, opposite changes in hsa-miR-1246 observed in different autoimmune disorders possibly indicate that the risk of coronavirus infection and COVID-19 may differ, depending on the particular disorder.

The above data demonstrate that expression of SARS-CoV-2-specific microRNAs changes differently in different human disorders. It should be noted additionally that SARS-CoV-2 infection also affects the functional state of the cell, in particular, by modulating gene transcription.

\section{SARS-CoV-2 AS A SOURCE OF microRNAs AND A REGULATOR OF HOST microRNA EXPRESSION}

As is known, virus infection can change expression of genes, including microRNA genes, in host cells [94-96]. For example, differences in expression of 20 microRNAs in the blood serum were observed between healthy individuals and hepatitis $C$ patients. In particular, hsa-miR-23b, which specifically binds to the SARS-CoV-2 genome, showed a difference, occurring at a lower level in hepatitis C [96].

In vitro, human enterovirus 71 (HEV71), which is thought to be a leading cause of virus encephalitis in children in the majority of Asian countries, was shown to regulate expression of 69 microRNAs, including hsa-miR-1246, in neuroblastoma cells [94]. HEV71induced hsa-miR-1246 was found to regulate expression of $D L G 3$, which is associated with neurological disorders [94]. DLG3 is expressed in various tissues, including the frontal cortex of the brain [97], and is necessary for learning [98]. A conclusion was made in view of these data that hsa-miR-1246 is potentially involved in the pathogenesis of HEV71-induced virus encephalitis HEV71 [94].

Neurological disorders were observed in COVID-19 patients, including headache, dizziness, encephalopathy, delirium, cerebrovascular accidents, GuillainBarre syndrome, acute transverse myelitis, and acute encephalitis [99]. It is therefore possible that SARSCoV-2 regulates the level of hsa-miR-1246, which is often changed in various diseases, including those that affect the course of COVID-19 (Table 2). 
The effect of SARS-CoV-2 on gene expression was studied in infected cells. Infection with SARS-CoV-2 was found to regulate expression of 327 genes in human bronchial epithelial cells. The products of these genes are involved, in particular, in the inflammatory response and metabolic regulation [100].

Infection of primary epithelial cells of the human lung with MERS-CoV and SARS-CoV-2 caused at least a twofold change in expression of 127 and 50 genes (out of 44556 genes tested), respectively. Only eight of these genes were common for two infections and showed similar changes in both cases [101]. The finding indicates again that SARS-CoV-2 has specific interactions with human cells as compared with other coronaviruses.

When microRNAs were studied in blood samples from patients with moderate or severe COVID-19, four microRNA groups differing in expression level were isolated and found to potentially provide biomarkers of COVID-19 development [9]. The first group included hsa-miR-146a-5p, hsa-miR-21-5p, and hsa-miR-142-3p, which are always suppressed. The second group included the microRNAs (such as hsa-miR-3605-3p) that are always activated. The third group included the microRNAs that are activated only in severe COVID-19: in particular, hsa-miR-15b-5p, hsa-miR-486-3p, and hsa-miR-486-5p. The fourth group included the microRNAs that are suppressed only in severe infection: in particular, hsa-miR-181a-2-3p, hsa-miR-31-5p, and hsa-miR-99a-5p. Four of the microRNAs-hsa-miR-146a-5p, hsa-miR-21-5p, hsamiR-142-3p, and hsa-miR-15b-5p-were identified as potential factors involved in the pathogenesis of the infectious disease caused by SARS-CoV-2. Some of the findings agree with observations by other researchers. For example, the hsa-miR-146a-5p level in the blood was lower in patients who did not respond to tocilizumab used to treat COVID-19, and the lowest levels were observed in patients with unfavorable outcomes of coronavirus infection [84].

Among the microRNAs that showed a changed blood content in COVID-19 patients [9], one microRNA, hsa-miR-142-3p, was assigned to the SARS-CoV-2-specific category (Table 1). Opposite changes in its level were observed in diseases (Table 2). Lower levels of hsa-miR-142-3p were detected in certain heart pathologies [63], while its higher levels were observed in complications of diabetes mellitus [71]. The following conclusion stems from the data. Even when targets for microRNAs are found in the SARS$\mathrm{CoV}-2$ genome, the pathogenetic significance of these molecules is important to evaluate with due regard to what functions they perform in the body and how favorable the conditions created with their involvement are for infection. It is possible to assume that a lower level of hsa-miR-142-3p is favorable for SARS$\mathrm{CoV}-2$ infection. In addition, the role (protective, unfavorable, or neutral) of particular microRNAs in
COVID-19 development may change depending on the disease stage and clinical features.

Coronaviruses, including SARS-CoV-2, can modify the microRNA profiles of host cells by acting as human microRNA sponges to facilitate virus replication or to evade the host immune response [29, 102]. This is possible because the regions of SARS-CoV-2 genome are complementary to several human microRNAs and because the virus RNA content in the cell is rather high, varying from 0.1 to $50 \%$ of total cell RNA [102], while the portion of host microRNAs is as low as approximately $0.01 \%$ (cited according to [29]).

Acting as a sponge, the SARS-CoV-2 genome can block not only human microRNAs, but also RNAbinding proteins, which play an important role in posttranslational regulatory networks of human cells [100]. The interaction with RNA-binding proteins of human cells is thought to help the SARS-CoV-2 genome to evade the host RNA degradation mechanisms, including those that involve human microRNAs [22]. In other words, the SARS-CoV-2 genome excludes the microRNA, mRNA, or protein molecules that are potentially significant for the response to infection from the physiological processes occurring in the infected cell and thus creates the conditions that favor its propagation and spreading in the human body. In particular, to explain excess expression of CSF1 in alveolar and bronchial epithelial cells after infection with SARS-CoV-2, it was assumed that the coronavirus genome (and the $\mathrm{S}$ protein gene in particular) competes with hsa-miR-1207-5p, which has target sites in the CSF1 mRNA [103]. High-level CSF1 expression in epithelial cells presumably contributes to uncontrollable inflammation in the most severe COVID-19 cases [103].

RNA viruses are capable of producing viral microRNAs (v-miRNAs, also termed small viral RNAs (svRNAs)) and thus play a role in the epigenetic regulation of the genome function in infected cells [10, $15,19,95,104]$. SARS-CoV svRNAs that originate from the $n s p 3$ genome region and the $\mathrm{N}$ protein gene (svRNA-N) and are 18-22 nt in size had a pathogenetic significance because in vivo inhibition of svRNA-N substantially decreased damage to the lung and expression of proinflammatory cytokines in mice infected with SARS-CoV [95]. It is noteworthy that svRNA biogenesis depended on the extent of virus replication.

In silico data are accumulating to indicate that the SARS-CoV-2 genome has regions that can produce microRNAs with a potential to epigenetically regulate the human genome. Khan et al. [19] found that the SARS-CoV and SARS-CoV-2 genomes can produce 126 and 170 mature v-miRNAs, respectively. SARS$\mathrm{CoV}$ and SARS-CoV-2 v-miRNAs target 5292 and 6369 human genes, respectively, and only 2992 genes are common for the two sets. SARS-CoV-2 v-miRNAs target not only the genes that help the virus to evade 
the host immune response, but also the genes whose products are involved in heart and brain development, the insulin signaling pathway, etc. [19]. Their interactions presumably contribute to the clinical features of patients with cardiovascular, endocrine, and other comorbidities.

In another study [15], 29 regions of the SARS$\mathrm{CoV}-2$ genome were identified as potential precursors of $\mathrm{v}$-miRNAs capable of targeting 1367 human genes. The targets of these v-miRNAs included the mRNAs of proteins involved in important cell processes, such as transcription, metabolism, cell defense, and Wnt and EGFR signaling pathways. For example, 96 target genes of v-miRNAs are involved in transcriptional regulation in human cells. The set includes genes for components of the Mediator complex (MED1, MED9, $M E D 12 L$, and $M E D 19$ ), general transcription factors (TAF4, TAF5, and TAF7L), site-specific transcription factors $(S T A T 1)$, etc.

Only six putative v-miRNAs are considered as key factors in the development of cytokine storm; these $\mathrm{v}$-miRNAs target the genes related to proliferation, differentiation, signaling, cell aging, and regulation of the immune response (the TNF and chemokine signaling pathways) [10]. These v-miRNAs are highly conserved and are therefore promising for vaccine development.

Experimental studies indicate that mature microRNA-like molecules can indeed be produced by SARS-CoV-2 to affect gene expression in infected cells. For example, Merino et al. [105] experimentally confirmed (by RNA sequencing) the expression of eight such molecules in cultured Calu-3 human lung cancer cells infected with SARS-CoV-2. It is noteworthy that the v-miRNAs structurally differed from known human microRNAs, but potentially targeted 109 genes that were differentially expressed after infection with SARS-CoV-2, and 28 of these genes were suppressed in virus-infected cells.

To summarize, although studies in the field started not long ago, data are accumulating to suggest or demonstrate that human microRNAs as well as the SARS-CoV-2 genome and microRNAs play a role in infection and the clinical course of COVID-19. The data indicate that microRNAs that are critical for the processes are difficult to identify. Tens of microRNAs were found to be potentially capable of binding to the SARS-CoV-2 genome. Opposite changes in their expression were observed in various disorders, including those that affect the risk of SARS-CoV-2 infection and the severity of COVID-19.

microRNAs expression changes observed in pathological conditions are not always possible to unequivocally identify as favorable or unfavorable factors in the risk and course of COVID-19. It is necessary to consider the functional role of each particular microRNA (including a role in creating favorable conditions for SARS-CoV-2 infection) and the process that the given microRNA marks (a normal physiological state, a stage of a pathological process, disease severity, drug response, etc.). It is important to note that SARS$\mathrm{CoV}-2$ is also capable of affecting the function of infected cells and the total body; modulating the gene expression levels in the cell; and producing v-miRNAs, which have a potential to contribute to the epigenetic regulation of the genome in infected cells.

\section{COMPLIANCE WITH ETHICAL STANDARDS}

Conflict of interests. The authors declare that they have no conflict of interest.

Statement on the welfare of humans or animals. This article does not contain any studies involving humans or animals performed by any of the authors.

\section{SUPPLEMENTARY INFORMATION}

The online version contains supplementary material available at https://doi.org/10.1134/S0026893322010034.

\section{REFERENCES}

1. Ejaz H., Alsrhani A., Zafar A., Javed H., Junaid K., Abdalla A.E., Abosalif K.O.A., Ahmed Z., Younas S. 2020. COVID-19 and comorbidities: Deleterious impact on infected patients. J. Infect. Publ. Hlth. 13 (12), 1833-1839.

2. Fulzele S., Sahay B., Yusufu I., Lee T.J., Sharma A., Kolhe R., Isales C.M. 2020. COVID-19 virulence in aged patients might be impacted by the host cellular microRNAs abundance/profile. Aging Dis. 11 (3), 509-522.

3. Callender L.A., Curran M., Bates S.M., Mairesse M., Weigandt J., Betts C.J. 2020. The impact of pre-existing comorbidities and therapeutic interventions on COVID-19. Front. Immunol. 11, 1991.

4. Jutzeler C.R., Bourguignon L., Weis C.V., Tong B., Wong C., Rieck B., Pargger H., Tschudin-Sutter S., Egli A., Borgwardt K., Walter M. 2020. Comorbidities, clinical signs and symptoms, laboratory findings, imaging features, treatment strategies, and outcomes in adult and pediatric patients with COVID-19: A systematic review and meta-analysis. Travel. Med. Infect. Dis. 37, 101825.

5. Murk W., Gierada M., Fralick M., Weckstein A., Klesh R., Rassen J.A. 2021. Diagnosis-wide analysis of COVID-19 complications: An exposure-crossover study. CMAJ. 193 (1), E10-E18.

6. Chang W.T., Toh H.S., Liao C.T., Yu W.L. 2021. Cardiac Involvement of COVID-19: A comprehensive review. Am. J. Med. Sci. 361 (1), 14-22.

7. Avila J., Long B., Holladay D., Gottlieb M. 2021. Thrombotic complications of COVID-19. Am. J. Emerg. Med. 39, 213-218.

8. Collantes M., Espiritu A.I., Sy M., Anlacan V., Jamora R. 2021). Neurological manifestations in COVID19 infection: A systematic review and meta-analysis. Can. J. Neurol. Sci. 48(1), 66-76. 
9. Tang H., Gao Y., Li Z., Miao Y., Huang Z., Liu X., Xie L., Li H., Wen W., Zheng Y., Su W. 2020. The noncoding and coding transcriptional landscape of the peripheral immune response in patients with COVID-19. Clin. Transl. Med. 10 (6), e200.

10. Satyam R., Bhardwaj T., Goel S., Jha N.K., Jha S.K., Nand P., Ruokolainen J., Kamal M.A., Kesari K.K. 2021. miRNAs in SARS-CoV-2: A spoke in the wheel of pathogenesis. Curr. Pharm. Des. 27 (13):1628-1641.

11. Chow J.T., Salmena L. 2020. Prediction and analysis of SARS-CoV2-targeting microRNA in human lung epithelium. Genes. 11 (9), 1002.

12. Jafarinejad-Farsangi S., Jazi M.M., Rostamzadeh F., Hadizadeh M. 2020. High affinity of host human microRNAs to SARS-CoV-2 genome: An in silico analysis. Noncoding RNA Res. 5 (4), 222-231.

13. Guo L., Yu J., Yu H., Zhao Y., Chen S., Xu C., Chen F. 2015. Evolutionary and expression analysis of miR-\#-5p and miR-\#-3p at the miRNAs/isomiRs levels. Biomed. Res. Int. 2015, 168358.

14. Guterres A., de Azeredo Lima C.H., Miranda R.L., Gadelha M.R. 2020. What is the potential function of microRNAs as biomarkers and therapeutic targets in COVID-19. Infect. Genet. Evol. 85, 104417.

15. Saçar Demirci M.D., Adan A. 2020. Computational analysis of microRNA-mediated interactions in SARS-CoV-2 infection. Peer. J. 8, e9369.

16. Huang Z., Shi J., Gao Y., Cui C., Zhang S., Li J., Zhou Y., Cui Q. 2019. HMDD v3.0: a database for experimentally supported human microRNA-disease associations. Nucleic Acids Res. 47 (D1), D1013-D1017.

17. Zhao X., Wang Y., Sun X. 2020. The functions of microRNA-208 in the heart. Diabetes Res. Clin. Pract. 160, 108004.

18. Chan A.P., Choi Y., Schork N.J. 2020. Conserved genomic terminals of SARS-CoV-2 as coevolving functional elements and potential therapeutic targets. mSphere. 5 (6), e00754-20.

19. Khan M.A., Sany M., Islam M.S., Islam A. 2020. Epigenetic regulator miRNA pattern differences among SARS-CoV, SARS-CoV-2, and SARS-CoV-2 worldwide isolates delineated the mystery behind the epic pathogenicity and distinct clinical characteristics of pandemic COVID-19. Front. Genet. 11, 765.

20. Abu-Izneid T., AlHajri N., Mohammed Ibrahim A., Noushad Javed M., Mustafa Salem K., Hyder Pottoo F., Amjad Kamal M. 2021. Micro-RNAs in the regulation of immune response against SARS-CoV-2 and other viral infections. J. Adv. Res. 30, 133-145.

21. Aydemir M.N., Aydemir H.B., Korkmaz E.M., Budak M., Cekin N., Pinarbasi E. 2021. Computationally predicted SARS-COV-2 encoded microRNAs target NFKB, JAK/STAT and TGFB signaling pathways. Gene Rep. 22, 101012.

22. Mukherjee M., Goswami S. 2020. Global cataloguing of variations in untranslated regions of viral genome and prediction of key host RNA binding protein-microRNA interactions modulating genome stability in SARS-CoV-2. PLoS One. 15 (8), e0237559.

23. Farshbaf A., Mohtasham N., Zare R., Mohajertehran F., Rezaee S.A. 2021. Potential therapeutic approaches of
microRNAs for COVID-19: challenges and opportunities. J. Oral. Biol. Craniofac. Res. 11 (2), 132-137.

24. Girardi E., López P., Pfeffer S. 2018. On the importance of host microRNAs during viral infection. Front. Genet. 9, 439.

25. Ludwig N., Leidinger P., Becker K., Backes C., Fehlmann T., Pallasch C., Rheinheimer S., Meder B., Stähler C., Meese E., Keller A. 2016. Distribution of miRNA expression across human tissues. Nucleic Acids Res. 44 (8), 3865-3877.

26. de Rie D., Abugessaisa I., Alam T., Arner E., Arner P., Ashoor H., Åström G., Babina M., Bertin N., Burroughs A.M., Carlisle A.J., Daub C.O., Detmar M., Deviatiiarov R., Fort A., et al. 2017. An integrated expression atlas of miRNAs and their promoters in human and mouse. Nat. Biotechnol. 35 (9), 872-878.

27. Sardar R., Satish D., Birla S., Gupta, D. 2020. Integrative analyses of SARS-CoV-2 genomes from different geographical locations reveal unique features potentially consequential to host-virus interaction, pathogenesis and clues for novel therapies. Heliyon. 6 (9), e04658.

28. Pierce J.B., Simion V., Icli B., Pérez-Cremades D., Cheng H.S., Feinberg M.W. 2020. Computational analysis of targeting SARS-CoV-2, viral entry proteins ACE2 and TMPRSS2, and interferon genes by host microRNAs. Genes. 11 (11), 1354.

29. Bartoszewski R., Dabrowski M., Jakiela B., Matalon S., Harrod K.S., Sanak M., Collawn J.F. 2020. SARSCoV-2 may regulate cellular responses through depletion of specific host miRNAs. Am. J. Physiol. Lung Cell Mol. Physiol. 319 (3), L444-L455.

30. Hosseini Rad Sm A., McLellan A.D. 2020. Implications of SARS-CoV-2 mutations for genomic RNA structure and host microRNA targeting. Int. J. Mol. Sci. 21 (13), 4807.

31. Arisan E.D., Dart A., Grant G.H., Arisan S., Cuhadaroglu S., Lange S., Uysal-Onganer P. 2020. The prediction of miRNAs in SARS-CoV-2 genomes: hsamiR databases identify 7 key miRs linked to host responses and virus pathogenicity-related KEGG pathways significant for comorbidities. Viruses. 12 (6), 614.

32. Balmeh N., Mahmoudi S., Mohammadi N., Karabedianhajiabadi A. 2020. Predicted therapeutic targets for COVID-19 disease by inhibiting SARS-CoV-2 and its related receptors. Inform. Med. Unlocked. 20, 100407.

33. Kozomara A., Birgaoanu M., Griffiths-Jones S. 2019. miRBase: From microRNA sequences to function. Nucleic Acids Res. 47 (D1), D155-D162.

34. Nersisyan S., Engibaryan N., Gorbonos A., Kirdey K., Makhonin A., Tonevitsky A. 2020. Potential role of cellular miRNAs in coronavirus-host interplay. Peer $J$. 8, e9994.

35. Naqvi A., Fatima K., Mohammad T., Fatima U., Singh I.K., Singh A., Atif S.M., Hariprasad G., Hasan G.M., Hassan M.I. 2020. Insights into SARSCoV-2 genome, structure, evolution, pathogenesis and therapies: Structural genomics approach. Biochim. Biophys. Acta Mol. Basis Dis. 1866 (10), 165878.

36. Li J., Huang D.Q., Zou B., Yang H., Hui W.Z., Rui F., Yee N., Liu C., Nerurkar S.N., Kai J., Teng M., Li X., Zeng H., Borghi J.A., Henry L., et al. 2021. Epidemi- 
ology of COVID-19: a systematic review and metaanalysis of clinical characteristics, risk factors, and outcomes. J. Med. Virol. 93 (3), 1449-1458.

37. Musri M.M., Coll-Bonfill N., Maron B.A., Peinado V.I., Wang R.S., Altirriba J., Blanco I., Oldham W.M., Tura-Ceide O., García-Lucio J., de la Cruz-Thea B., Meister G., Loscalzo J., Barberà J.A. 2018. MicroRNA dysregulation in pulmonary arteries from chronic obstructive pulmonary disease. relationships with vascular remodeling. Am. J. Respir. Cell Mol. Biol. 59 (4), 490-499.

38. Sundar I.K., Li D., Rahman I. 2019. Small RNA-sequence analysis of plasma-derived extracellular vesicle miRNAs in smokers and patients with chronic obstructive pulmonary disease as circulating biomarkers. J. Extracell. Vesicles. 8 (1), 1684816.

39. Cazorla-Rivero S., Mura-Escorche G., GonzalvoHernández F., Mayato D., Córdoba-Lanús E., Casanova C. 2020. Circulating miR-1246 in the progression of chronic obstructive pulmonary disease (COPD) in patients from the BODE cohort. Int. J. Chron. Obstruct. Pulmon. Dis. 15, 2727-2737.

40. Shi L., Xin Q., Chai R., Liu L., Ma Z. 2015. Ectopic expressed miR-203 contributes to chronic obstructive pulmonary disease via targeting TAK1 and PIK3CA. Int. J. Clin. Exp. Pathol. 8 (9), 10662-10670.

41. Wei C., Henderson H., Spradley C., Li L., Kim I.K., Kumar S., Hong N., Arroliga A.C., Gupta S. 2013. Circulating miRNAs as potential marker for pulmonary hypertension. PLoS One. 8 (5), e64396.

42. Huber L.C., Ulrich S., Leuenberger C., Gassmann M., Vogel J., von Blotzheim L.G., Speich R., Kohler M., Brock M. 2015. Featured article: MicroRNA-125a in pulmonary hypertension: regulator of a proliferative phenotype of endothelial cells. Ex. Biol. Med. Maywood). 240 (12), 1580-1589.

43. Jardim M.J., Dailey L., Silbajoris R., Diaz-Sanchez D. 2012. Distinct microRNA expression in human airway cells of asthmatic donors identifies a novel asthma-associated gene. Am. J. Respir. Cell. Mol. Biol. 47 (4), 536-542.

44. Ke X.F., Fang J., Wu X.N., Yu C.H. 2014. MicroRNA203 accelerates apoptosis in LPS-stimulated alveolar epithelial cells by targeting PIK3CA. Biochem. Biophys. Res. Commun. 450 (4), 1297-1303.

45. Marketou M.E., Kontaraki J.E., Maragkoudakis S., Patrianakos A., Konstantinou J., Nakou H., Vougia D., Logakis J., Chlouverakis G., Vardas P.E., Parthenakis F.I. 2018. MicroRNAs in peripheral mononuclear cells as potential biomarkers in hypertensive patients with heart failure with preserved ejection fraction. Am. J. Hypertens. 31 (6), 651-657.

46. Huang X., Li Z., Bai B., Li X., Li Z. 2015. High expression of microRNA-208 is associated with cardiac hypertrophy via the negative regulation of the sex-determining region Y-box 6 protein. Exp., Ther. Med. 10 (3), 921-926.

47. Kontaraki J.E., Marketou M.E., Parthenakis F.I., Maragkoudakis S., Zacharis E.A., Petousis S., Kochiadakis G.E., Vardas P.E. 2015. Hypertrophic and antihypertrophic microRNA levels in peripheral blood mononuclear cells and their relationship to left ven- tricular hypertrophy in patients with essential hypertension. J. Am. Soc. Hypertens. 9 (10), 802-810.

48. Wang G., Kwan B.C., Lai F.M., Choi P.C., Chow K.M., Li P.K., Szeto C.C. 2010. Intrarenal expression of miRNAs in patients with hypertensive nephrosclerosis. Am. J. Hypertens. 23 (1), 78-84.

49. Liu W., Zheng J., Dong J., Bai R., Song D., Ma X., Zhao L., Yao Y., Zhang H., Liu T. 2018. Association of miR-197-5p, a circulating biomarker for heart failure, with myocardial fibrosis and adverse cardiovascular events among patients with stage $\mathrm{C}$ or $\mathrm{D}$ heart failure. Cardiology. 141 (4), 212-225.

50. Wong L.L., Armugam A., Sepramaniam S., Karolina D.S., Lim K.Y., Lim J.Y., Chong J.P., Ng J.Y., Chen Y.T., Chan M.M., Chen Z., Yeo P.S., Ng T.P., Ling L.H., Sim D., et al. 2015. Circulating microRNAs in heart failure with reduced and preserved left ventricular ejection fraction. Eur. J. Heart Fail. 17 (4), 393-404.

51. Hu Q., Luo W., Huang L., Huang R., Chen R. 2016. Apoptosis-related microRNA changes in the right atrium induced by remote ischemic perconditioning during valve replacement surgery. Sci. Rep. 6, 18959.

52. He X., Ji J., Wang T., Wang M.B., Chen X.L. 2017. Upregulation of circulating miR-195-3p in heart failure. Cardiology. 138 (2), 107-114.

53. Liu H., Yang N., Fei Z., Qiu J., Ma D., Liu X., Cai G., Li S. 2016. Analysis of plasma miR-208a and miR-370 expression levels for early diagnosis of coronary artery disease. Biomed. Rep. 5 (3), 332-336.

54. Liu W., Ling S., Sun W., Liu T., Li Y., Zhong G., Zhao D., Zhang P., Song J., Jin X., Xu Z., Song H., Li Q., Liu S., Chai M., et al. 2015. Circulating microRNAs correlated with the level of coronary artery calcification in symptomatic patients. Sci. Rep. 5, 16099.

55. van Rooij E., Sutherland L.B., Liu N., Williams A.H., McAnally J., Gerard R.D., Richardson J.A., Olson E.N. 2006. A signature pattern of stress-responsive microRNAs that can evoke cardiac hypertrophy and heart failure. Proc. Natl. Acad. Sci. U. S. A. 103 (48), 1825518260.

56. Zhang X., Ji R., Liao X., Castillero E., Kennel P.J., Brunjes D.L., Franz M., Möbius-Winkler S., Drosatos K., George I., Chen E.I., Colombo P.C., Schulze P.C. 2018. MicroRNA-195 regulates metabolism in failing myocardium via alterations in sirtuin 3 expression and mitochondrial protein acetylation. Circulation. 137 (19), 2052-2067.

57. Weber K., Rostert N., Bauersachs S., Wess G. 2015. Serum microRNA profiles in cats with hypertrophic cardiomyopathy. Mol. Cell. Biochem. 402 (1-2), 171180.

58. Slagsvold K.H., Johnsen A.B., Rognmo O., Høydal M.A., Wisløff U., Wahba A. 2014. Mitochondrial respiration and microRNA expression in right and left atrium of patients with atrial fibrillation. Physiol. Genomics. 46 (14), 505-511.

59. Cañón S., Caballero R., Herraiz-Martínez A., PérezHernández M., López B., Atienza F., Jalife J., HoveMadsen L., Delpón E., Bernad A. 2016. miR-208b upregulation interferes with calcium handling in $\mathrm{HL}-1$ 
atrial myocytes: Implications in human chronic atrial fibrillation. J. Mol. Cell. Cardiol. 99, 162-173.

60. Long G., Wang F., Duan Q., Yang S., Chen F., Gong W., Yang X., Wang Y., Chen C., Wang D.W. 2012. Circulating miR-30a, miR-195 and let-7b associated with acute myocardial infarction. PLoS One. 7 (12), e50926.

61. Boštjančič E., Brandner T., Zidar N., Glavač D., Štajer D. 2018. Down-regulation of miR-133a/b in patients with myocardial infarction correlates with the presence of ventricular fibrillation. Biomed. Pharmacother. 99, 65-71.

62. Li C., Fang Z., Jiang T., Zhang Q., Liu C., Zhang C., Xiang Y. 2013. Serum microRNAs profile from genome-wide serves as a fingerprint for diagnosis of acute myocardial infarction and angina pectoris. $B M C$ Med. Genomics. 6, 16.

63. Nair N., Kumar S., Gongora E., Gupta S. 2013. Circulating miRNA as novel markers for diastolic dysfunction. Mol. Cell. Biochem. 376 (1-2), 33-40.

64. Wang Y.F., Lian X.L., Zhong J.Y., Su S.X., Xu Y.F., Xie X.F., Wang Z.P., Li W., Zhang L., Che D., Yu L., Huang P., Jia H.L., Gu X.Q. 2019. Serum exosomal microRNA let-7i-3p as candidate diagnostic biomarker for Kawasaki disease patients with coronary artery aneurysm. IUBMB Life. 71 (7), 891-900.

65. He L.P., Zhao X.S., He L.P. 2018. Abnormally expressed miR-23b in Chinese Mongolian at high cardiovascular risk may contribute to monocyte/macrophage inflammatory reaction in atherosclerosis. Biosci. Rep. 38 (6), BSR20180673.

66. Zampetaki A., Kiechl S., Drozdov I., Willeit P., Mayr U., Prokopi M., Mayr A., Weger S., Oberhollenzer F., Bonora E., Shah A., Willeit J., Mayr M. 2010. Plasma microRNA profiling reveals loss of endothelial miR126 and other microRNAs in type 2 diabetes. Circ. Res. 107 (6), 810-817.

67. Zhao B., Li H., Liu J., Han P., Zhang C., Bai H., Yuan X., Wang X., Li L., Ma H., Jin X., Chu Y. 2016. MicroRNA-23b targets Ras GTPase-activating protein $\mathrm{SH} 3$ domain-binding protein 2 to alleviate fibrosis and albuminuria in diabetic nephropathy. J. Am. Soc. Nephrol. 27 (9), 2597-2608.

68. Párrizas M., Brugnara L., Esteban Y., GonzálezFranquesa A., Canivell S., Murillo S., Gordillo-Bastidas E., Cussó R., Cadefau J.A., García-Roves P.M., Servitja J.M., Novials A. 2015. Circulating miR-192 and miR-193b are markers of prediabetes and are modulated by an exercise intervention. J. Clin. Endocrinol. Metab. 100 (3), E407-E415.

69. Kim H., Bae Y.U., Jeon J.S., Noh H., Park H.K., Byun D.W., Han D.C., Ryu S., Kwon S.H. 2019. The circulating exosomal microRNAs related to albuminuria in patients with diabetic nephropathy. J. Transl. Med. 17 (1), 236.

70. Torella D., Ellison G.M., Torella M., Vicinanza C., Aquila I., Iaconetti C., Scalise M., Marino F., Henning B.J., Lewis F.C., Gareri C., Lascar N., Cuda G., Salvatore T., Nappi G., et al. 2014. Carbonic anhydrase activation is associated with worsened pathological remodeling in human ischemic diabetic cardiomyopathy. J. Am. Heart Assoc. 3 (2), e000434.
71. Friedrich J., Steel D.H.W., Schlingemann R.O., Koss M.J., Hammes H.P., Krenning G., Klaassen I. 2020. microRNA expression profile in the vitreous of proliferative diabetic retinopathy patients and differences from patients treated with anti-VEGF therapy. Transl. Vis. Sci. Technol. 9 (6), 16.

72. Dubois-Camacho K., Diaz-Jimenez D., De la Fuente M., Quera R., Simian D., Martínez M., Landskron G., Olivares-Morales M., Cidlowski J.A., Xu X., Gao G., Xie J., Chnaiderman J., Soto-Rifo R., González M.J., et al. 2019. Inhibition of miR-378a-3p by inflammation enhances IL-33 levels: a novel mechanism of alarmin modulation in ulcerative colitis. Front. Immunol. 10, 2449.

73. Zhu S., Pan W., Song X., Liu Y., Shao X., Tang Y., Liang D., He D., Wang H., Liu W., Shi Y., Harley J.B., Shen N., Qian Y. 2012. The microRNA miR-23b suppresses IL-17-associated autoimmune inflammation by targeting TAB2, TAB3 and IKK- $\alpha$. Nat. Med. 18 (7), 1077-1086.

74. Krissansen G.W., Yang Y., McQueen F.M., Leung E., Peek D., Chan Y.C., Print C., Dalbeth N., Williams M., Fraser A.G. 2015. Overexpression of miR-595 and miR-1246 in the sera of patients with active forms of inflammatory bowel disease. Inflamm. Bowel Dis. 21 (3), 520-530.

75. Méndez-Flores S., Furuzawa-Carballeda J., Hernández-Molina G., Ramírez-Martinez G., ReginoZamarripa N.E., Ortiz-Quintero B., Jiménez-Alvarez L., Cruz-Lagunas A., Zúñiga J. 2019. MicroRNA expression in cutaneous lupus: A new window to understand its pathogenesis. Mediators Inflamm. 2019, 5049245.

76. Hiratsuka I., Yamada H., Munetsuna E., Hashimoto S., Itoh M. 2016. Circulating microRNAs in Graves' disease in relation to clinical activity. Thyroid. 26 (10), $1431-1440$.

77. Tsigaris P., Teixeira da Silva J.A. 2020. Smoking prevalence and COVID-19 in Europe. Nicotine Tob. Res. 22 (9), 1646-1649.

78. Liu S., Cao Y., Du T., Zhi Y. 2020. Prevalence of comorbid asthma and related outcomes in COVID-19: A systematic review and meta-analysis. J. Allergy Clin. Immunol. Pract. 9 (2), 693-701.

79. Wakabayashi M., Pawankar R., Narazaki H., Ueda T., Itabashi T. 2021. Coronavirus disease 2019 and asthma, allergic rhinitis: Molecular mechanisms and hostenvironmental interactions. Curr. Opin. Allergy Clin. Immunol. 21 (1), 1-7.

80. Inchley C.S., Sonerud T., Fjærli H.O., Nakstad B. 2015. Nasal mucosal microRNA expression in children with respiratory syncytial virus infection. $B M C$ Infect. Dis. 15, 150.

81. Zhu X., Ge Y., Wu T., Zhao K., Chen Y., Wu B., Zhu F., Zhu B., Cui L. 2020. Co-infection with respiratory pathogens among COVID-2019 cases. Virus Res. 285, 198005.

82. Zhang H., Rostami M.R., Leopold P.L., Mezey J.G., O'Beirne S.L., Strulovici-Barel Y., Crystal R.G. 2020. Expression of the SARS-CoV-2 ACE2 receptor in the human airway epithelium. Am. J. Respir. Crit. Care Med. 202 (2), 219-229. 
83. Azevedo R.B., Botelho B.G., Hollanda J., Ferreira L., Junqueira de Andrade L.Z., Oei S., Mello T.S., Muxfeldt E.S. 2021. COVID-19 and the cardiovascular system: A comprehensive review. J. Hum. Hypertens. 35 (1), 4-11.

84. Sabbatinelli J., Giuliani A., Matacchione G., Latini S., Laprovitera N., Pomponio G., Ferrarini A., Baroni S.S., Pavani M., Moretti M., Gabrielli A., Procopio A.D., Ferracin M., Bonafè M., Olivieri F. 2020. Decreased serum levels of the inflammaging marker miR-146a are associated with clinical response to tocilizumab in COVID-19 patients. Mech. Ageing Dev. 193, 111413.

85. Kabeerdoss J., Pilania R.K., Karkhele R., Kumar T.S., Danda D., Singh S. 2021. Severe COVID-19, multisystem inflammatory syndrome in children, and Kawasaki disease: immunological mechanisms, clinical manifestations and management. Rheumatol. Int. 41 (1), 19-32.

86. Sokolovsky S., Soni P., Hoffman T., Kahn P., Scheers-Masters J. 2021. COVID-19 associated Kawasaki-like multisystem inflammatory disease in an adult. Am. J. Emerg. Med. 39, 253.e1-253.e2.

87. Alsaied T., Tremoulet A.H., Burns J.C., Saidi A., Dionne A., Lang S.M., Newburger J.W., de Ferranti S., Friedman K.G. 2021. Review of cardiac involvement in multisystem inflammatory syndrome in children. Circulation. 143 (1), 78-88.

88. Galeotti C., Bayry J. 2020. Autoimmune and inflammatory diseases following COVID-19. Nat. Rev. Rheumatol. 16 (8), 413-414.

89. Wolff D., Nee S., Hickey N.S., Marschollek M. 2021. Risk factors for Covid-19 severity and fatality: a structured literature review. Infection. 49 (1), 15-28.

90. Zhou Y., Chi J., Lv W., Wang Y. 2021. Obesity and diabetes as high-risk factors for severe coronavirus disease 2019 (COVID-19). Diabetes Metab. Res. Rev. 37 (2), e 3377.

91. Monteleone G., Ardizzone S. 2020. Are patients with inflammatory bowel disease at increased risk for COVID-19 infection? J. Crohns Colitis. 14 (9), 13341336.

92. Favalli E.G., Ingegnoli F., De Lucia O., Cincinelli G., Cimaz R., Caporali R. 2020. COVID-19 infection and rheumatoid arthritis: Faraway, so close! Autoimmun. Rev. 19 (5), 102523.

93. Liu Y., Sawalha A.H., Lu Q. 2021. COVID-19 and autoimmune diseases. Curr. Opin. Rheumatol. 33 (2), $155-162$.

94. Xu L.J., Jiang T., Zhao W., Han J.F., Liu J., Deng Y.Q., Zhu S.Y., Li Y.X., Nian Q.G., Zhang Y., Wu X.Y., Qin E.D., Qin C.F. 2014. Parallel mRNA and microRNA profiling of HEV71-infected human neuroblastoma cells reveal the up-regulation of miR-1246 in association with DLG3 repression. PLoS One. 9 (4), e95272.

95. Morales L., Oliveros J.C., Fernandez-Delgado R., tenOever B.R., Enjuanes L., Sola I. 2017. SARS-CoVencoded small RNAs contribute to infection-associated lung pathology. Cell Host Microbe. 21, 344-355.

96. El-Hefny M., Fouad S., Hussein T., Abdel-Hameed R., Effat H., Mohamed H., Abdel Wahab A.H. 2019. Circulating microRNAs as predictive biomarkers for liver disease progression of chronic hepatitis $\mathrm{C}$ (genotype-4. Egyptian patients. J. Med. Virol. 91 (1), 93-101.

97. Bastian F.B., Roux J., Niknejad A., Comte A., Fonseca Costa S.S., de Farias T.M., Moretti S., Parmentier G., de Laval V.R., Rosikiewicz M., Wollbrett J., Echchiki A., Escoriza A., Gharib W.H., Gonzales-Porta M., et al. 2021. The Bgee suite: Integrated curated expression atlas and comparative transcriptomics in animals. $\mathrm{Nu}$ cleic Acids Res. 49 (D1), D831-D847.

98. UniProt Consortium. 2021. UniProt: The universal protein knowledgebase in 2021. Nucleic Acids Res. 49 (1), D480-D489.

99. Ahmad I., Rathore F.A. 2020. Neurological manifestations and complications of COVID-19: A literature review. J. Clin. Neurosci. 77, 8-12.

100. Srivastava R., Daulatabad S.V., Srivastava M., Janga S.C. 2020. Role of SARS-CoV-2 in altering the RNA-binding protein and miRNA-directed posttranscriptional regulatory networks in humans. Int. J. Mol. Sci. 21 (19), 7090.

101. Jang Y., Seo S.H. 2020. Gene expression pattern differences in primary human pulmonary epithelial cells infected with MERS-CoV or SARS-CoV-2. Arch. Virol. 165 (10), 2205-2211.

102. Blanco-Melo D., Nilsson-Payant B.E., Liu W.C., Uhl S., Hoagland D., Møller R., Jordan T.X., Oishi K., Panis M., Sachs D., Wang T.T., Schwartz R.E., Lim J.K., Albrecht R.A., tenOever B.R. 2020. Imbalanced host response to SARS-CoV-2 drives development of COVID-19. Cell. 181 (5), 1036-1045.e9.

103. Bertolazzi G., Cipollina C., Benos P.V., Tumminello M., Coronnello C. 2020. miR-1207-5p can contribute to dysregulation of inflammatory response in COVID-19 via targeting SARS-CoV-2 RNA. Front Cell Infect. Microbiol. 10, 586592.

104. Mishra R., Kumar A., Ingle H., Kumar H. 2020. The interplay between viral-derived miRNAs and host immunity during infection. Front. Immunol. 10, 3079.

105. Merino G.A., Raad J., Bugnon L.A., Yones C., Kamenetzky L., Claus J., Ariel F., Milone D.H., Stegmayer G. 2021. Novel SARS-CoV-2 encoded small RNAs in the passage to humans. Bioinformatics. 36 (24), 5571-5581. 